land on this scale is closing down our future options. Ominously, the rate of increase in yields of basic crops such as maize, wheat, and soyabeans, is declining.

We can be encouraged that Governments and their people are becoming more and more aware of the dangers, but erosion is still easily winning the race. The scientific and technical solutions are known, now consisting of a great body of knowledge on how to stop desert encroachment and conserve soils. But all too often the poor farmer has no access to even the most basic expertise and technology, and even when they are available, what seems sound economic sense to the planner, fails to appeal to a peasant concerned primarily with feeding his growing family.

\section{Conclusion}

Appropriate land-tenure is crucial. When the farmer feels insecure, the tendency is to mine the land until it is no longer productive, then to move on elsewhere to repeat the process. Involvement is the key: there is an urgent need to involve the villagers at all stages of development. If Governments seriously want their farmers to reduce their herds or to stop ploughing steep slopes or to replant trees, then the authorities must provide proposals that people will accept. If we are to have any realistic hopes of adequately feeding the projected turnof-the-century population of over six thousand million people, Governments must engineer a switch to a more frugal, more conserving, agriculture. If we are to arrest the destruction of our environment, people must be educated to appreciate that it is in their overwhelming self-interest to do so. As the Chinese philosopher Kwand $\mathrm{Zu}$ wrote:

'If you plan for one year, plant rice.

If you plan for ten, plant trees.

If you plan for one hundred years, educate mankind.'

\title{
Possible Approach to Explaining Strange Behaviour of Surging Glaciers
}

Scientists think they have the answer to what causes the curious behaviour of 'surging glaciers' that accelerate dramatically from time to time, unlike normal slowmoving masses of ice. The cause of such surges has been a major mystery in the understanding of glaciers in general. Now the US National Research Foundation (NSF) has announced that research workers studying a glacier in Alaska have reported that its periodic surges are associated with increases in water-pressures beneath the glacier, which affect its base and cause it to slide very rapidly. The increased pressures are related to changes in the shape and motion of the glacier which inhibit drainage of water along the base of the ice - according to these workers, who think that similar conditions may have contributed to the rapid collapse of some of the huge ice-sheets that covered much of North America and Europe during the Pleistocene Epoch, from about 1.5 million to 12,000 years ago.

The scientists who reported their findings to the NSF are Professor Charles F. Raymond, of the University of Washington, Seattle, Dr William D. Harrison, of the University of Alaska, and Professor W. Barclay Kamb, of the California Institute of Technology, Pasadena. They are studying a mass of ice called the Variegated Glacier - so-named because of the multicoloured rocks piled in front of it as it moves down a valley towards the sea about 30 miles $(48 \mathrm{~km})$ east of the tiny fishing village of Yakuta, lying to the north-west of Juneau. The Glacier is almost 15 miles $(24 \mathrm{~km})$ long and 6,000 feet $(1,829 \mathrm{~m})$ high at its source. It is one of the smaller ones of the surging type, and probably the most studied, having been observed and photographed since about 1900 . Until now, however, no extensive measurements have been made of the behaviour of the Glacier, which surges every 18 to 20 years.

The latest, anticipated surge of the Variegated Glacier started in January 1982, when surface velocities of the ice reached as much as 30 feet ( $c a 9 \mathrm{~m}$ ) a day in early summer and returned to its near-normal velocities of three to six feet per day during the late summer and fall. The glacier began to speed up again in November 1982 , and by spring of 1983 the speed had reached up to 180 feet ( $c a 55 \mathrm{~m}$ ) a day. The surge stopped abruptly in early July, when large amounts of water drained out of the glacier.

A variety of techniques were used to measure the Glacier's movement, including time-lapse photography for which cameras were placed along adjacent walls of the valley. Markers on the ice were surveyed, sometimes as frequently as each hour, during the summer months. Also, holes were drilled through the ice and instruments placed in them to measure water pressure at the base of the Glacier and differences in the flow-rate between the top and bottom layers of ice. Water discharged from the Glacier also was measured, and aerial photographs were taken periodically to monitor the overall movement of the glacier. The Variegated Glacier is in a remote area, where floods from the surge pose no danger. However, other glaciers are near inhabited regions where a surge could threaten lives and property.

RALPH KAZARIAN
National Science Foundation
1800 G Street
Washington
DC 20550
USA.

RaLPH KaZARIAN

National Science Foundation Washington

USA.

\section{World Policy Institute: Programme Description}

\section{Purpose}

The World Policy Institute is a non-profit research and public education organization located in New York City. It formulates practical policy recommendations on United States and world economic and security issues, and promotes them to the policy-making community and the public. Institute programmes stress the develop- ment of 'world policies' — policies that reflect the shared needs and interests of all nations and that can, over time, help to reshape the political and intellectual context within which all governments operate.

The political process in the USA has opened-up considerably in recent years and there is now a fresh opportunity to inculcate new, positive initiatives into the 